ROCZNIKI HUMANISTYCZNE

Volume 67, issue $4-2019$

SELECTED PAPERS IN ENGLISH

DOI: http://dx.doi.org/10.18290/rh.2019.67.4-2en

EWA KUBIAK

\title{
CUZCO SCHOOL PAINTING (ESQUELA CUSQUEÑA) AS A MANIFESTATION OF ANDEAN IDENTITY IN THE PAST AND PRESENT
}

\section{THE COLONIAL PAINTING OF CUZCO (ESCUELA CUSQUEÑA)}

The painting of the Cuzco school developed in the city of Cuzco proper and in the Cuzco region in the $17^{\text {th }}$ and $18^{\text {th }}$ centuries and is marked as one of the most remarkable artistic phenomenon of the Peruvian highlands in the colonial period. ${ }^{1}$ On the one hand, it draws on Dutch art; on the other, it firmly rests on

Ewa KubiaK, PhD—Department of Art History, Łódź University, ul. Narutowicza 65, 90-131 Łódź; e-mail: lalibela@tlen.pl

The Polish version of the article was published in Roczniki Humanistyczne vol. 65, issue 4 (2017).

${ }^{1}$ There are multiple works and studies on Cuzco painting. The most conclusive work is a 1982 two-volume publication by Teresa Gisbert i José de Mesa (Jose DE MESA, Teresa GisBERT, Historia de la pintura cuzqueña (La Paz: Fundación A.N. Wiese, 1982)). However, their first attempt to address the subject had been made 20 years before: Jose DE MESA, Teresa GisBERT, Historia de la pintura cuzqueña (Buenos Aires: Univ. de Buenos Aires, Facultad de arquitectura y urbanismo, 1962). The earliest publications are: Felipe COSSIO y DEL POMAR, Historia crítica de la pintura en el Cuzco, Cuzco 1922 and the later publication of Pintura colonial: escuela cuzqueña (Cuzco: Universidad de Cuzco, 1928); Ricardo MARIÁtegui Oliva, Pintura cuzqueña del siglo XVII: los maravillosos lienzos del Corpus existentes en la Iglesia de Santa Ana del Cuzco (Lima: Alma Mater, Distribuidores, 1951). Some more contemporary ones include: Alfredo HinojosA GÁlvez, La pintura cusqueña en la ideología Andina (Lima: Victor Alfredo Hinojosa Gálvez, 2012); Vito D’Alessio, Manuel J. VerA DEL CARPIO, A arte mestiça: Escola Cusquenha de Pintura (São Paulo: Dialeto, 2012). There are also many publications in which Cuzco painting is present, yet discussed only cursorily: Gabriela SIRACUSANO, El poder de los colores. De lo material a lo simbólico en las practicas culturales andinas. Siglos XVI-XVII (Buenos Aires: Fondo de Cultura Económica de Argentina, 2005); Barroco peruano, 
the indigenous tradition which manifests itself in rich colours, the presence of elements of local flora and fauna, gilding (pan de oro), and local Marian and Christological references. The impact of Cuzco painting was not limited to the Cuzco region only. Paintings from Cuzco are to be found in remote locations of the Viceroyalty of Peru as well (Argentina, Bolivia, Chile) and in many archives, e.g. in the inventories of Jesuit missions in the Mojos and Chiquitos re gion compiled in connection with the 1767 expulsion of Jesuits. Today they are stored in the Sucre archives.

Paintings from the studies of Cuzco school artists are exhibited, for example, in: La Paz (Museo Nacional de Arte), Sucre (Museo Charcas), Santiago de Chile (Museo de Arte Colonial de San Francisco), Kordobie (Museo de Arte Religioso Juan de Tejeda y Monasterio de Santa Teresa), Potosi (Museo de Casa Nacional de Moneda; Museo y Convento de Santa Teresa; Museo y Convento de Sanfrancisco) and Buenos Aires (Museo Hispanoamericano Isaac Fernández Blanco). They are also displayed across many Christian temples of northern Argentina, just to mention Nuestra Señora de la Candelaria w Cochinoca, San Francisco de Paula y Santa Cruz in Uquía or Nuestra Señora de la Asunción in Casabindo. ${ }^{2}$

Historical sources also provide abundant information about the popularity of Cuzco painting. A description of the mission of Santísima Trinidad de Mojos (eastern borderland of Bolivia), mentions "the image made in Cusco Nuestra Señora de Belén in a decorated chest," ${ }^{3}$ and in a report from the mission of San Javier de Chiquitos, the source speaks of "one roll of Cuzco painting." 4 Perhaps also other accounts on rolled canvas can be referred to Cuzco paintings, such as those retrieved from the mission of San Pedro de Mojos ("two rolls of painted

ed. Ramon Mujica Pinilla (Lima: Banco de Crédito del Peru, 2002); Barroco peruano 2, ed. Ramon Mujica Pinilla (Lima: Banco de Crédito del Peru, 2003); Carolyn DeAn, Los cuerpos de los Incas y el cuerpo de Cristo. El Corpus Christi en el Cuzco Colonial (Lima: Universidad Nacional Mayor de San Marcos and Banco Santander Central Hispano, 2002 [revised edition of 1999]).

${ }^{2}$ Marta Penhos, "Pintura de la región Andina: algunas reflexiones en torno a la vida de las formas y sus significados," in Pintura de los reinos, vol. III, Identidades compartidas. Territorios del Mundo hispánico, siglos XVI-XVIII, ed. Juana Gutiérrez Haces (Mexico: México, D.F.: Fomento Cultural Banamex, 2009), 848-849, 870-871.

${ }^{3}$ Archivo y Biblioteca Nacional de Bolivia [ABNB], MyCh, vol. 1, I, f.8 v.: "un Linzo hecho en Cuzco de Nuestra Señora de Belén en un cajonsito adornado."

${ }^{4}$ ABNB, MyCh, vol. 24, II, f.56 r.: "un rollo de la pintura cusqueña." 
canvas featuring the Passion of Christ" ${ }^{, 5}$ ) or concerning, more explicitly, Estancia de Abana ("five canvases with four separate representations of various invocations"6). It is known of the Cuzco school that its authors would paint several images on a single, large canvas and would separate one from another with floral frames, so that they could easily be divided into individual scenes. Several such items have been found uncut. One of such canvas depicts St Dominic and St Francis; it has been uncovered in the pinacotheca at the Monastery of Santa Catalina de Siena in Arequipa (Peru) ${ }^{7}$ (Img. 1). An even more suggestive picture is the one from the Church of San Francisco de Paula y Santa Cruz in Uquía (Argentina) which shows Christ the Sorrowful, the Virgin Mary and two representations of Madonna Lactans (Img. 2). Marta Penhos described this kind of work as "almost mass production" typical of the $18^{\text {th }}$ century, ${ }^{8}$ and Gabriela Siracusano dates the tradition of mass canvas production even to the $17^{\text {th }}$ century. ${ }^{9}$

There is a strong and popular belief that Cuzco painting is an example of cultural mestization - there is even a term for that in colonial art research: arte mestizo. Certainly, Cuzco images reveal Spanish (colonial) and native (Indian) features, both in the formal and semantic layer. Very frequent elements featured on images that allude to the local tradition are dishes, Inca costumes or local rituals symbolized by, for example, keros (cups for drinking chicha) and coca leaves.

Some are of the opinion that The Last Supper (1753) by the Indian artist Marcos Zapata showcased in the Cuzco cathedral shows a roasted guinea piga traditional course from the Andean region - instead of the Paschal lamb on the supper table. ${ }^{10}$ The guinea pig is known in the Andes as cuy. ${ }^{11}$ In the Indian

\footnotetext{
${ }^{5}$ ABNB, MyCh, vol. 1, I, f.27 r.: "dos rollos de lienzos pintados de la pasión de Christo."

${ }^{6}$ SiRACUSANO, El poder de los colores, 160: "sinco lienzos con quattro guarniciones de diferentes advocaciones."

${ }^{7}$ The painting was photographed by the author during her field research in Peru in May 2015.

${ }^{8}$ Penhos, "Pintura de la región Andina," 848.

${ }^{9}$ SiRACUSANO, El poder de los colores, 160.

${ }^{10}$ In Polish, see: Janusz Z. WoŁoszyn, "Dziwne losy świnki morskiej (po obu stronach Atlantyku)," Przegląd Historyczny 102, issue 4 (2011): 635; Marcin F. GAWRYCKI, Chrystus jada cuy. Latynoamerykańska sztuka kulinarna nie od kuchni (Warszawa: Muzeum Historii Ruchu Ludowego, 2014, 15; HiNOJOSA GÁlveZ, "La pintura," 306; the image was based on a graphics by Christoph Thomas Scheffler and Martin Engelbrecht „Agnus Dei Qui Tollis Peccata Mundi Miserere Nobis,” but, instead of an empty plate on the graphics, the image shows a roasted guinea pig and fruits on the table.

${ }^{11}$ The dish, i.e. roasted guinea pig, is referred to as "cuy asado" or "cuy al horno" (when grilled). The guinea pig in the local cuisine is not a thing of the past; its meat is still on Peruvian tables and is
} 
tradition, it is not only part of the local menu but also a sacrificial animal. ${ }^{12}$ For this reason, as Marcin Gawrycki puts it, its presence on the table during the Last Supper is absolutely understandable for the local population. ${ }^{13}$

Portrait was not known in the Inca tradition. First images reflecting the physiognomic features of a person appeared in South America with the arrival of the Spanish, who also spread the custom of creating rulers' portraits highlighting their relevant attributes. Several such series of portraits made it to Spain; others were used to decorate the interiors of Andean residences of the Inca nobility "in a European fashion". ${ }^{14}$ Images of Indians can also be found in paintings exploring religious themes and documenting certain historic or religious events. One of the most famous of them is an anonymous series of paintings documenting the procession of Corpus Christi in Cuzco and created during the term of Bishop Manuel de Molliendo y Angulo (1673-1699). The series is a remarkable iconographic record capturing the extraordinary splendour of the Cuzco holiday. ${ }^{15}$ The Inca nobility, although keeping up with the Spanish fashion in clothes on a daily basis, in official portraits or images painted during religious holidays, they are often portrayed in traditional costumes with items or accessories emphasizing their position in the social hierarchy, for example, the Inca tunic (unku) or the ornamental cap (mascaypacha) worn by the royalty. In official situations, the Inca nobility were seen as the intermediate level or mediator bringing the two cultures and communities-Indian (local) and colonial

a very important source of protein for the inhabitants of the Andean highlands. WoŁoszyn, "Dziwne losy świnki," 645 . The dish is increasingly popular in restaurants, not only those visited by the locals: Ewa KUBIAK, Quechuismos en el espacio público del Cusco y su región cercana (MA paper written in the Department of Spanish Studies, Łódź University, under the supervision of Prof. W. Nowikowa) (Łódź: Wydawnictwo Uniwersytetu Łódzkiego, 2016), 93.

${ }^{12}$ Daniel H. SAndweIss, Elizabeth S. WIng, "Ritual Rodents: The Guinea Pigs of Chincha, Peru," Journal of Field Archaeology 24, issue 1 (1997): 54-56; WoŁosZYN, “Dziwne losy świnki,” 645-647.

${ }^{13}$ GAWRYCKI, Chrystus jada cuy, 15.

${ }^{14}$ One such series, depicting the pre-Columbian rulers of Peru, was ordered by Viceroy Francisco de Toledo in 1572; he sent it to Madrid to King Philip II. The paintings perished in a fire in 1734; Carolyn DeAn, "Inka Nobles: Portraiture and Paradox in Colonial Peru," in Exploring New World Imagery, ed. Donna Pierce (Denver: Denver Art Museum, 2005), 81-82.

${ }^{15}$ The series was intended for Santa Ana's Church in Cusco. The $19^{\text {th }}$-century inventory lists 18 images, but today we can identify 16, 12 of which are available in the Museo Arzobispal del Arte Religioso in Cuzco and four in private collections in Santiago de Chile; DEAn, Los cuerpos, 61. 
(Spanish) - together. ${ }^{16}$ The contrast between the European and Inca dress is clearly seen in a double portrait by Marcos Zapata of the mid-18 ${ }^{\text {th }}$ century. The painting made for the Jesuit church in Cuszo presents two couples at the time of marriage vows: the captain and conquistador Martín de Loyola and ñusta (Inca princess) Beatriz, the daughter of an Inca named Sayri Tupak, and Juan de Borja and Lorenza ñusta de Loyola. ${ }^{17}$ The costume of the Inca princess Beatriz and the members of her family and court clearly stand out against that of the Europe$\operatorname{ans}^{18}$ (Img. 3).

In this short description of the output of the Cuzco school of painting, also the painted themes should be discussed. Our Lady (Madonna) seemed to be the most popular theme. Multiple iconographic types were created. The local tradition is certainly reflected in the representations of Virgen de Belén (along with the story of the miraculous arrival of the image to Cuzco), Virgen de Suntur huasi (Our Lady who saved the city conquered by Spanish conquistadors from being re-taken by rebellious Indians), Virgen de Cocharcas (Img. 4), Virgen de Pomata and other images known across Europe but painted in a completely different style, such as Virgen del Rosario or Virgen de la Candelaria. The most revered images of Christ include Christ Crucified or Christ of the Earthquakes (Cristo de los Temblores) from the Cuzco cathedral. ${ }^{19}$ This image was reproduced multiple times, and it is primarily known from painting interpretations outside Cuzco (Img. 5). Evidence of worship related to local invocations is found in very remote areas. Again, the inventories from the regions of Jesuit missions among the Mojo Indians can be used as a reliable source. In addition to the Cuzco images of Virgen de Belem discussed earlier, the inventories also mention other "miraculous pictures" from Cuzco. The records from the mission of Santa Magdalena list "three large silver nails for the Holy Christ of the Earthquakes that come from this original [representation] worshiped in the sa-

\footnotetext{
${ }^{16}$ Ibidem, 115-117.

${ }^{17}$ Luis E. Wuffarden, "Iglesia y Colegio de la Transfiguración, Cuzco, Perú," in Fundaciones jesuíticas en Iberoamérica, ed. Luisa E. Alcalá (Madrid: Fundacion Iberdrola, 2002), 126.

${ }^{18}$ Teresa GiSBERT, Iconografía y mitos indigenas en el arte (La Paz: Gisbert, 2008), 153-157.

${ }^{19}$ Christ of the Earthquakes is also known as Taytacha de los Temblores; the name was partly derived from the Quechua language. "Tayta" in Quechua means "father," "master," and "taytacha" is understood as "God, our father, our master;" KUBIAK, Quechuismos, 118.
} 
cred cathedral of Cuzco" as revered items. ${ }^{20}$ The San Pedro mission had a separate chapel dedicated to Virgen de Cocharcas. ${ }^{21}$ That worshipped Marian image was stored in a shrine halfway between Cuzco and Ayacucho. This iconographic type is remarkable. Our Lady is depicted on the altar (or a processional platform) under a canopy. In the background and below the altar, the image shows pilgrimages to the shrine and scenes from rural life. ${ }^{22}$ The image has been known since the early $17^{\text {th }}$ century and resembles the well-known representation of Virgen de Copacabana. Our Lady of Cocharcas is one of the most original iconographic types of the Viceroyalty of Peru. ${ }^{23}$ The image in question enjoyed the greatest popularity in the second half of the 18 th century. ${ }^{24}$

Another recurring theme of Andean painting is angels. The most popular figure is Archangel Michael, who was portrayed not only in numerous paintings but also in sculptures or reliefs on church façades. Another important character is Archangel Raphael portrayed with his typical attribute (fish), referring to the biblical story of Tobias. Also, other Raphael's images were made that are less known in Europe, e.g. such as Raphael with Thrones or Powers, and the depictions of angels with arquebuses as in the region of the Andes. ${ }^{25}$

In conclusion, it should be stressed that the artistic medium was relatively easy to change in the Andean region and in the city of Cuzco. Many sculpture works were reproduced on painted canvas, very often with the original background. The paintings feature fragments of richly gilded altars, candlesticks or

${ }^{20}$ ABNB, MyCh, vol. 1, I, f. 58 r.: "tres clavos grandes de plata para el Santo Christo de los Temblores sacado por el original, que se venera en la santa catedral del Cusco."

${ }^{21}$ ABNB, MyCh, vol. 1, I, f. 24 r.

${ }^{22}$ Museo Pedro de Osma, [catalogue] (Lima: Fundacion Pedro y Angelica de Osma Gildemeister, 2004), 86-87; Carol Damian, The Virgin of the Andes. Art and Ritual in Colonial Cuzco (Miami Beach: Grassfield Press, Incorporated, 1995), 57-58.

${ }^{23}$ Hector Schenone, Santa María. Iconografia del Arte Colonial (Buenos Aires: Educa, Editorial de la Universidad Católica Argentina, 2008), 351-353.

${ }^{24}$ Luisa E. AlCALÁ, "The image of the Devout Indian: the Codification of Colonial Idea," in Contested Visions in the Spanish Colonial World, ed. Ilona Katzew (Los Angeles: Los Angeles County Museum of Art, 2012), 241-242.

${ }^{25}$ Ramon Mujica Pinilla, Ángeles apócrifos en la América virreinal (Lima: Fondo de Cultura Económica, 1996 [1992]), 249-269; José DE MesA, Teresa GisBert, “Ángeles y arcángeles," in El retorno de los Ángeles, ed. José de Mesa (La Paz: Union Latina, 1996), 38-51; Ewa KuBiAK, "Motyw anioła w sztuce obszaru andyjskiego Wicekrólestwa Peru," in Anioł w literaturze i kulturze, vol. I, ed. Jolanta Ługowska, Jacek Skawiński (Wrocław: Oficyna Wydawnicza Atut, 2004), 387-393. 
flower vases placed before sacred images. This can be associated with the Spanish tradition of clothing sacred statues (especially images of Our Lady). Often, on the initiative of the sponsor of a new costume, the new version of the revered image was labelled, and the visible fragments left of the original sculpture were most often only the face and hands. ${ }^{26}$ This custom was relatively widespread in Latin America. Black and white graphics (both European and local) were used as models followed by painters who created new and original compositions by adding colours, adornments, and gilding. ${ }^{27}$ Olga Isabel Acosta Luna also emphasizes that at the sculpting stage the prototypes of painting interpretations were prepared with remarkable accuracy; she even takes the liberty of calling this trend "obsessive realism" achieved through colourful polychrome, clothes, and jewellery. The sculpted Mother of God should have looked like a "living woman" while the painting interpretations were not intended to portray the actual Virgin Mary but her real and sanctified image with surroundings. ${ }^{28}$ An example of this phenomenon is a canvas of the revered figure of the Mother of God from the Copacabana shrine, which is now on display in La Recoleta Convent in Cuzco, or the painting representation of Virgen de Cocharcas mentioned earlier (Img. 4).

\section{CONTEMPORARY NEO-BAROQUE PAINTING OF CUZCO}

The Baroque Cuzco painting is not a thing of the past. Today, studies offering neocolonial paintings imitating the old style are not uncommon. Certainly, the modern devotional art of Cuzco is not limited to copies of Baroque painting but happens to go as far as to offer a creative interpretation of colonial rendi-

\footnotetext{
${ }^{26}$ For printed copies of Marian images, see also: David FrEEDBERG, Potega wizerunków. Studia $z$ historii $i$ teorii oddziaływania, translated by Ewa Klekot (Kraków: Wydawnictwo Uniwersytetu Jagiellońskiego, 2005 [1989]), 114-123; Maya STANFIELD-MAZZI, Object and Apparition. Envisioning the Christian Divine in the Colonial Andes (Tucson: University of Arizona Press, 2013), 139-146.

${ }^{27}$ Suzanne L. Stratton-Pruit, “'Dressed Sculpture' Paintings,” in Journeys to New Worlds. Spanish and Portuguese colonial art in the Roberta and Richard Huber Collection, ed. Suzanne L. Stratton-Pruit, Mark A. Castro (Philadelphia: Philadelphia Museum of Art, 2013), 66.

${ }^{28}$ Olga I. Acosta LunA, Milagrosas Imagenes marianas en el Nuevo Reino de Granada (MadridFrankfurt am Main: Iberoamericana, 2011), 397; see also: Luisa E. AlCALÁ, "On perceptions of Value in Colonial Art," in Journeys, 23.
} 
tions. The former San Blas district has still retained its flavour of an old artistic colony; in dozens of its little stores, you can buy contemporary artisanal handicraft (artesania). The splendour and richness of neo-Baroque items still attracts buyers' attention. There is where you can find copies of colonial paintings, even made using the same technique as years ago (oil on canvas), although with present-day tools and materials. ${ }^{29}$

Most works created in Cuzco today remain anonymous, as was the case in the Baroque (Imgs. 6, 7). Only few artists sign their works and sell them in their own galleries. It is still mostly a collective effort. Many works are created in three separate studies: one artist paints landscapes and clothes, another one faces and hands, and yet another one applies gilding. If so wished by the customer, some paintings are "aged" to achieve a characteristic Baroque painting colour (Img. 8, 9). The sequence of operations is not always maintained, and only outstanding masters are able to complete the entire work on their own. Copies of colonial paintings fulfil a devotional role in Cuzco or other cities in Peru and South America. The representation of Virgen de Belén is a good example. This colonial canvas depicting the journey of the sacred image was painted by Basilia de Santa Cruz Pumacalla in the years 1693-1698. Its full title is Virgen de Belén con el obispo Manuel de Mallinedo y Angulo como donante. ${ }^{30}$ It was made for the Cuzco cathedral and has remained there ever since. How ever, the faithful of Nuestra Señora de Belén's native parish also wanted a similar work in their temple and ordered a copy to be displayed in the church chancel (Img. 10). Research on the neo-Baroque painting of Cuzco has only just begun. Two books have been published so $\operatorname{far}^{31}$ and several popular science articles by Italian authors.

The popularity of the Baroque painting in Cuzco is not fading at all. During the "live" painting competition held by the municipal authorities (Qosqoruna) in 2014 , two categories were proposed. The jury assessed "freestyle" images and

\footnotetext{
${ }^{29}$ Alfredo Pacheco Venero, the owner of a small shop, Galería de Artesanía "Fenix", introduced me to the world of neo-Baroque painting. In 2008 I was able to see for the first time how neocolonial paintings are made and learn about the successive stages of the painting process.

${ }^{30}$ Virgen de Belén with the donor, Bishop Manuelem de Mallinedo y Angulo.

${ }^{31}$ Riccardo Scотті, Barocco Andino: Arcangeli guerrieri, madonne e dee, santi meticci (Torino: Ananke, 2009); Riccardo ScotTi, Massimo Centini, Barocco Andino Contemporáneo: Arcangeles guerreros, virgenes y diosas, Santos mestizos (Verdello-Bergamo: Corriere dell'arte, 2013).
} 
paintings following the neo-Baroque Cuzco convention. The winner was Artemio Coanqui Carrasco, and brothers William and Robert Quispe Huari received honourable mentions. All these artists work on their own although Artemio sometimes seeks assistance with gilding.

William and Robert are loyal copiers of colonial paintings. The former graduated from an arts academy, the latter is a self-made artist. Their works are faithful imitations of Diego Quispe Tito's (Img. 11) or Marcos Zapata's style. They do not focus on glamorous gilding - this is one of multiple elements of Cuzco painting - but primarily draw on the Dutch tradition, strongly penetrating Andean painting, especially in the 17th century. For both artists, neo-Baroque painting is one of their preferred styles, although not the only one; yet, they both emphasize that such paintings sell better and at higher prices than others. ${ }^{32}$

Artemio Coanqui Carrasco is a representative of the older generation ${ }^{33}$ (born 22 February 1967). He graduated from the Academia de Bellas Artes in Cuzco named after Diego Quispe Tito. However, he claims that he was never taught traditional painting techniques at the Cuzco academy. After taking a chance with modern painting for some time, Artemio returned to traditional painting. He regards his paintings as unique works, not mere copies of colonial paintings. He signs some of them. He often adds items that did not exist on the original colonial canvases. He experiments with background landscapes by making them more homogeneous in colour, golden or silver. He attributes complex Indian symbolism to some elements, which is completely non-transparent to the average audience. Sometimes, as other artists, he makes his painting characters wear costumes made of traditional Indian fabric. Next to the images of Our Lady (Img. 14), angels and archangels often feature in Artemio's works (Imgs. 12, 14). The artist also paints compositions depicting Christ, gospel scenes, for ex ample, Ecce Homo or the Last Supper; he also frequently alludes to the Inca and mestizo traditions (Img. 11).

\footnotetext{
${ }^{32}$ Interview with the artists was held in Roberto Nilton Quispe Huari's study on 20.06.2015.

${ }^{33}$ Interview with the artist held in Artemio Coanqui Carrasco's study on 17 June 2015.
} 


\section{NEO-BAROQUE PAINTING AS AN ELEMENT OF IDENTIFICATION IN THE PURSUIT OF REGIONAL IDENTITY}

After Peru regained independence, Cuzco became a symbol of the ancient Inca empire and a place of "awakening" of national remembrance. Public ceremonies held after the victory over the Spanish Crown clearly defined the direct relations between the Incas and liberators. In 1825 a victory parade in Cuzco started from the former Qorikancha temple and ended in front of the town hall. This was to highlight a link between the former glory and the hopeful future. This process advanced during the confederation (1936-1939), although it seems that it was not so much advocated by the head of state, Andres de Santa Cruz, but was the outcome of the efforts of the Cuzco community. ${ }^{34}$

After stagnation and regression in the second half of the $19^{\text {th }}$ century, the turn of the $19^{\text {th }}$ century saw major changes. The period was marked by a shift in the mindset of both the mestizo-Indian peasantry and the Peruvian intellectual elite of Peru. ${ }^{35}$ The problem of discrimination against Indians in the mountainous regions of Peru (sierra) became more visible to the general public. Indigenists and reformists from the academic circles were the most ardent advocates of the "Indian cause" in the period. The early $20^{\text {th }}$ century is a period of an increased activity of indigenous organizations and groups. Its rich history, imperial past and social conditions made Cuzco one of the main centres stimulating the growth of reformist and revival currents associated with Indian communities. ${ }^{36}$ The 1920s saw the rise of a phenomenon referred to as cusqueñismo. Initially, it was linked to indigenous movements but later became identified with local patriotism and strong self-identification of the Cuzco people for whom the city

\footnotetext{
${ }^{34}$ Natalia MAJLUF, "De la rebelión al. museo. Genealogías y retratos de los incas 1781-1900," in Los incas, reyes del Perú, ed. Thomas Cummins (Lima: Banco de Crédito, 2005), 276-279.

${ }^{35}$ For more on the shift of awareness and indigenous movements in Cuzco and the phenomenon of cusqueñismo, see: Ewa KUBIAK, Reinterpretacje. Percepcja i recepcja dziel architektury na przyktadzie światyń jezuickich Ameryki Poludniowej okresu kolonialnego (Łódź: Wydawnictwo Uniwersytetu Łódzkiego, 2015), 217-220.

${ }^{36}$ Marta KANIA, “1909-2009: ewolucja idei cusqueñismo w stulecie ruchu Reformy Uniwersyteckiej w Cusco," in Ruchy spoleczne i etniczne w Ameryce Lacińskiej, ed. Karol Derwich, Marta Kania (Kraków: Wydawnictwo Uniwersytetu Jagiellońskiego, 2011), 100-104; Joanna PIETRASZCZYKSĘKOwSKA, Tradycje oporu w Andach. Mobilizacje indiańskochłopskie w Peru od XVI do XX wieku (Łódź: Wydawnictwo Uniwersytetu Łódzkiego, 2015), 138.
} 
was something to be proud of. Cusqueñismo was vividly described and debated both in the local intellectual circles and among the residents. ${ }^{37}$ It seems that the demand for "cusqueñizar a los cusqueños" was embedded in the life of the local community. ${ }^{38}$ A fundamental element of the idea cusqueñismo is identification with the city of Cuzco and the entire region. Initially, it was the Inca traditions and the golden period before the arrival of the Spanish that were referred to and admired in the first place; later on, the rich and colourful colonial legacy became also appreciated.

The 1950 earthquake was a pivotal moment when the people of Cuzco were forced to decide the future of their locality. The city was heavily affected: many churches and monasteries from the colonial period were in ruin. ${ }^{39}$ The Cuzco community had to decide whether and to what extent these buildings were considered important, and whether it was worth investing funds in restoring their former glory. Soon after, with the support of UNESCO which established a special commission coordinating the restoration work, ${ }^{40}$ not only the preHispanic monuments but also the colonial quarters were rebuilt. ${ }^{41}$

In the case of Cuzco, the sense of pride in own history, culture and monuments expanded both spatially and chronologically. It embraced not only the city proper but the entire region. The phenomenon of cusqueñismo began to cover not only the reminiscence of the former splendour of the Incas state but also the legacy of colonial times. Andean people's conviction of the great importance of their culture is extremely powerful. It is also a response to the isola-

\footnotetext{
${ }^{37}$ Miguel H. Milla, “Cincuenta años de cusqueñismo,” in Revista del Instituto Americano de Arte del Cusco 14 (1993-1994): 1-15; Tania GutiÉRrez SAmANEZ, "Las impulsoras del cusqueñismo y del Inti Raymi," in Revista del Instituto Americano de Arte del Cusco 14 (1993-1994): 47-54.

${ }^{38}$ Julio A. Gutiérrez Samanez, "Humberto Vidal y la creación de las fiestas del Cusco," in Revista del Instituto Americano de Arte del Cusco 4 (1993-1994): 23. The expression "cusqueñismo" was used for the first time by José Ángela Escalantego in his 1928 article published in Mundial; Carlos Nieto Degregori, "Tres momentos en la evolución del cusqueñismo," Márgenes. Encuentro y debate 7, issue 13-14 (1995): 114.

${ }^{39}$ Marta KanIA, Prekolumbijski image Peru. Rola archeologii i dziedzictwa inkaskiego $w$ ksztattowaniu peruwiańskiej tożsamości narodowej (Kraków: Wydawnictwo Uniwersytetu Jagiellońskiego, 2010), 283.

${ }^{40}$ Ibidem, 283-284.

${ }^{41}$ George Kubler, Cuzco: Reconstruction of the Town and Restoration of its Monuments (Paris: UNESCO, 1962).
} 
tion of the Indian community and the ruralisation of the sierra areas away from the capital.

Today's search for the region's identity is not limited to pre-Columbian times: the colonial heritage is also increasingly appreciated. For Cuzco artists, there is no division into separate Inca and colonial cultures. The tradition and history are one: they combine both elements of the European and of the local by creating their syncretic mix-cultural mestization. As the painters themselves say, Corpus Christi processions are as serious and important as the day-to-day cultivation of Indian traditions in the family, and the people of Cuzco admire both the colours and gilding of Baroque and neo-Baroque canvas as well as the melodic sound of the Quechua language.

\section{BIBLIOGRAPHY}

ABNB, MyCh, vol. 1, I-Archivo y Biblioteca Nacionales de Bolivia (Boliwia, Sucre). Fondo Mojos y Chiquitos, Colección Gabriel René-Moreno, Signatura: 1, I. Inventarios de los bienes, así de Iglesia como Temporalidad, secuestrados en los pueblos de Loreto, Trinidad, San Javier, San Pedro, Santa Ana, Exaltación, Magdalena, San Ignacio y Reyes desde del 4 de Octubre hasta el 16 de Diciembre de 1767 y son extendidos por los comisarios que para el efecto destacó el jefe de extrañamiento de Mojos Don Antonio Aymerich y formalizados por este en Loreto.

ABNB, MyCh, vol. 24, II-Archivo y Biblioteca Nacionales de Bolivia (Boliwia, Sucre). Fondo Mojos y Chiquitos, Colección Gabriel René-Moreno, Signatura: 24, II. Relación informativa sobre el estado y modo de ser general de las misiones de Chiquitos, y sobre arreglos para ellas consultados con vista de su ulterior gobierno y administración temporal y espiritual. Por el Itmo. Sr. Obispo dr D. Francisco Ramón de Herboso.

Acosta LunA, Olga Isabel. Milagrosas Imagenes marianas en el Nuevo Reino de Granada. MadridFrankfurt am Main: Iberoamericana, 2011.

AlCALÁ, Luisa Elena. "On perceptions of Value in Colonial Art.” In Journeys to New Worlds. Spanish and Portuguese colonial art in the Roberta and Richard Huber Collection, ed. Suzanne L. Stratton-Pruit, Mark A. Castro. Philadelphia: Philadelphia Museum of Art, 2013.

AlcalÁ, Luisa Elena. "The image of the Devout Indian: the Codification of Colonial Idea." In Contested Visions in the Spanish Colonial World, ed. Ilona Latzew. Los Angeles: Los Angeles County Museum of Law, 2012.

D’Alessio, Vito. Vera del Carpio Manuel Julio, A arte mestiça: Escola Cusquenha de Pintura. São Paulo: Dialeto, 2012.

Barroco peruano, ed. Ramón Mujica Pinilla. Lima: Banco de Crédito del Peru, 2002.

Barroco peruano 2, ed. Ramón Mujica Pinilla. Lima: Banco de Crédito del Peru, 2003. 
Cossio y del Pomar, Felipe. Historia crítica de la pintura en el Cuzco. Cuzco: Universidad de Cuzco, 1922.

Cossio y del Pomar, Felipe. Pintura colonial: escuela cuzqueña. Cuzco: Universidad de Cuzco, 1928.

Damian, Carol. The Virgin of the Andes. Art. and Ritual in Colonial Cuzco. Miami Beach: Grassfield Press, Incorporated, 1995.

DeAn, Carolyn. "Inka Nobles: Portraiture and Paradox in Colonial Peru." In Exploring New World Imagery, ed. Donna Pierce. Denver: Denver Art Museum, 2005.

DeAn, Carolyn. Los cuerpos de los Incas y el cuerpo de Cristo. El Corpus Christi en el Cuzco Colonial. Lima: Universidad Nacional Mayor de San Marcos and Banco Santander Central Hispano, 2002 [rev. 1999].

FreEdBerg, David. Potęga wizerunków. Studia z historii $i$ teorii oddziaływania. Transl. by Ewa Klekot. Kraków: Wydawnictwo Uniwersytetu Jagiellońskiego, 2005 [1989].

GAWRYCKI, Marcin Florian. Chrystus jada cuy. Latynoamerykańska sztuka kulinarna nie od kuchni. Warszawa: Biblioteka Iberyjska, 2014.

GiSBERT, Teresa. Iconografía y mitos indígenas en el arte. La Paz: Gisbert, 2008.

Gutiérrez Samanez, Julio A. "Humberto Vidal y la creación de las fiestas del Cusco." Revista del Instituto Americano de Arte del Cusco 14 (1993-1994).

GutiÉRrez Samanez, Tania. "Las impulsoras del cusqueñismo y del Inti Raymi.” Revista del Instituto Americano de Arte del Cusco 14 (1993-1994).

Hinojosa Gálvez, Alfredo. La pintura cusqueña en la ideología Andina. Lima: Victor Alfredo Hinojosa Gálvez, 2012.

KANIA, Marta. "1909-2009: ewolucja idei cusqueñismo w stulecie ruchu Reformy Uniwersyteckiej w Cusco.” In Ruchy społeczne i etniczne w Ameryce Lacińskiej, ed. Karol Derwich, Marta Kania. Kraków: Wydawnictwo Uniwersytetu Jagiellońskiego, 2011.

Kania, Marta. Prekolumbijski image Peru. Rola archeologii i dziedzictwa inkaskiego w ksztaltowaniu peruwiańskiej tożsamości narodowej. Kraków: Wydawnictwo Uniwersytetu Jagiellońskiego, 2010.

KubiaK, Ewa. "Motyw anioła w sztuce obszaru andyjskiego Wicekrólestwa Peru." In Anioł w literaturze $i$ kulturze. Vol. I, ed. Jolanta Ługowska and Jacek Skawiński. Wrocław: Oficyna Wydawnicza Atut, 2004.

KubIAK, Ewa. Quechuismos en el espacio público del Cusco y su región cercana (MA paper written in the Department of Spanish Studies, Łódź University, under the supervision of Prof. W. Nowikowa). Łódź: Wydawnictwo Uniwersytetu Łódzkiego, 2016.

KubIaK, Ewa. Reinterpretacje. Percepcja i recepcja dzieł architektury na przykładzie świątyń jezuickich Ameryki Poludniowej okresu kolonialnego. Łódź: Wydawnictwo Uniwersytetu Łódzkiego, 2015.

Kubler, George. Cuzco: Reconstruction of the Town and Restoration of its Monuments. Paris: UNESCO, 1962.

MAJluf, Natalia. "De la rebelión al. museo. Genealogías y retratos de los incas 1781-1900.” In Los incas, reyes del Perú, ed. Thomas Cummins. Lima: Banco de Crédito del Peru, 2005. 
Mariátegui Oliva, Ricardo. Pintura cuzqueña del siglo XVII: los maravillosos lienzos del Corpus existentes en la Iglesia de Santa Ana del Cuzco. Lima: Alma Mater, Distribudores, 1951.

Mesa De, José, Teresa Gisbert. “Ángeles y arcángeles.” In El retorno de los Angeles, ed. José de Mesa. La Paz: Union Latina, 1996.

Mesa de, José, Teresa Gisbert. Historia de la pintura cuzqueña. La Paz: Fundación A.N., 1982.

Mesa de, José, Teresa Gisbert. Historia de la pintura cuzqueña. Buenos Aires: Univ. de Buenos Aires, 1962.

Milla, Miguel H. "Cincuenta años de cusqueñismo.” Revista del Instituto Americano de Arte del Cusco 14 (1993-1994).

Mujica Pinilla, Ramón. Ángeles apócrifos en la América virreinal. Lima: Fondo de Cultura Económica, 1996 [rev. 1992].

Museo Pedro de Osma, [catalogue]. Lima: Fundacion Pedro y Angelica de Osma Gildemeister, 2004.

Nieto Degregori, Carlos. “Tres momentos en la evolución del cusqueñismo.” Márgenes. Encuentro $y$ debate 7, issue 13-14 (1995).

Penhos, Marta. "Pintura de la región Andina: algunas reflexiones en torno a la vida de las formas y sus significados." In Pintura de los reinos. Vol. III. Identidades compartidas. Territorios del Mundo hispánico, siglos XVI-XVIII, ed. Juana Gutierrez Haces. México: D.F.: Fomento Cultural Banamex, 2009.

PIETRASZCZYK-SęKOwsKa, Joanna. Tradycje oporu w Andach. Mobilizacje indiańskochłopskie w Peru od XVI do XX wieku. Łódź: Wydawnictwo Uniwersytetu Łódzkiego, 2015.

SAnDweIss, Daniel H., Elizabeth S. Wing. "Ritual Rodents: The Guinea Pigs of Chincha, Peru." Journal of Field Archaeology 24, issue 1 (1997).

Schenone, Héctor. Santa María. Iconografia del Arte Colonial. Buenos Aires: Educa, Editorial de la Universidad Católica Argentina, 2008.

ScotTI, Riccardo. Barocco Andino: Arcangeli guerrieri, madonne e dee, santi meticci. Torino: Ananke, 2009.

ScotTi, Riccardo, Massimo Centini. Barocco Andino Contemporáneo: Arcangeles guerreros, virgenes y diosas, Santos mestizos. Verdello-Bergamo: Corriere dell'arte, 2013.

SiRACuSAno, Gabriela. El poder de los colores. De lo material a lo simbólico en las practicas culturales andinas. Siglos XVI-XVII. Buenos Aires: Fondo de Cultura Económica, 2005.

Stanfield-MazzI, Maya. Object and Apparition. Envisioning the Christian Divine in the Colonial Andes. Tucson: University of Arizona Press, 2013.

Stratton-Pruit, Suzanne L. “'Dressed Sculpture' Paintings.” In Journeys to New Worlds. Spanish and Portuguese colonial art in the Roberta and Richard Huber Collection, ed. Suzanne L. Stratton-Pruit, Mark A. Castro. Philadelphia: Philadelphia Museum of Art, 2013.

WoŁoszYn, Janusz Z. “Dziwne losy świnki morskiej (po obu stronach Atlantyku).” Przegląd Historyczny 102 (2011), book 4.

Wuffarden, Luis Eduardo. "Iglesia y Colegio de la Transfiguración, Cuzco, Perú." In Fundaciones jesuiticas en Iberoamérica, ed. Luisa Elena Alcalá. Madrid: Fundacion Iberdrola, 2002. 


\section{LIST OF IMAGES}

1. Images of St Dominic and St Francis, pinacotheca at Santa Catalina Monastery in Arequipa (Peru); photo by E. Kubiak, 2015.

2. Canvas with four images (Christ the Sorrowful, Our Lady of Sorrows, two images of Madonna Lactans) from the church of San Francisco de Paula y Santa Cruz in Uquía (Argentina); Marta Penhos, "Pintura de la region Andina...," 871.

3. Marriage of captain-conquistador Martín de Loyola and ñusta Beatriz, daughter of an Inca named Sayri Tupak and of Juan de Borja and Lorenza ñusta de Loyola, $18^{\text {th }}$ century, Jesuit Church, Cuzco; Luis E. Wuffarden, "Iglesia y Colegio de la Transfiguración, Cuzco, Perú," 126.

4. Virgen de Cocharcas, anonymous painting, 1767, private collection, Lima (Carol Damian, The Virgin of the Andes..., 59); Virgen de Copacabana, $17^{\text {th }}$ century, anonymous painting, La Recoleta Convent in Cuzco, Peru (Luisa E. Alcalá, "On perceptions...," 23).

5. Cristo de los Temblores from the Cuzco cathedral, anonymous sculpture, $17^{\text {th }}$ century, Good Monday procession, Cuzco (photo by E. Kubiak, 2010); Cristo de los Temblores, anonymous painting, Las Nazarenas Monastery in Cuzco; photo by E. Kubiak, 2015.

6. Last Supper, anonymous painting, private collection; photo by E. Kubiak, 2015.

7. Virgen de Candelaria, anonymous painting, author's private collection; Cristo de los Temblores, anonymous painting, author's private collection; photo by E. Kubiak, 2016.

8. Luis Alfredo Pacheco Venero in his gallery working on finishing a new-Baroque painting portraying Angel the Arquebuser, Cuzco; photo by E. Kubiak, 2010.

9. Successive stages of production of contemporary neo-Baroque canvas in Cuzco, photos taken at the Galería de Artesanía "Fenix" in Cuzco (owner: Luis Alfredo Pacheco Venero); photo by E. Kubiak, 2013.

10. Basilio de Santa Cruz Pumacalla, Virgen de Belén con el obispo Manuel de Mallinedo y Angulo como donante (1693-1698), Catedral de Cusco, Perú; Copia de la obra de Basilio de Santa Cruz Pumacalla, Virgen de Belén con el obispo Manuel de Mallinedo y Angulo como donante, 2005, Iglesia de Nuestra Señora de Belén, Cusco, Perú; photo by E. Kubiak, 2012.

11. Thomas de Leu, St Sebastian, graphics modelled after the composition by Aegidius Sadaler II, based on a painting by Jacopo Palma the Younger; imitator of Diego Quipse Tito, St Sebastian, $17^{\text {th }}$ century, Museo de Santa Catalina, Cusco, Peru (source: www.colonialart.org); Robert Nilton Quispe Huari, St Sebastian, artist's own collection, study; photo by E. Kubiak, 2015.

12. Artemio Coanqui Carrasco, the painter showing off the image with Angel the Arquebuser, artist's own collection, study; photo by E. Kubiak, 2015.

13. Artemio Coanqui Carrasco, Marriage ceremony of a conquistador and ñusta, unfinished; Inca couple, sketch, artist's own collection, study; photo by E. Kubiak, 2015.

14. Artemio Coanqui Carrasco, Archangel Gabriel (fragment); Madonna with Child, artist's own collection, study; photo by E. Kubiak, 2015. 


\section{CUZCO SCHOOL PAINTING (ESQUELA CUSQUEÑA) \\ AS A MANIFESTATION OF ANDEAN IDENTITY IN THE PAST AND PRESENT}

\section{Summary}

Painting of the Cuzco school developed in the city proper and in the Cuzco region in the $17^{\text {th }}$ and $18^{\text {th }}$ centuries. Its influence was not limited to this area; information about the presence of paintings from Cuzco in distant regions of the Viceroyalty of Peru can be found in numerous sources. The tradition which acknowledged Cuzco painting to be a manifestation of cultural mestization is extremely strong. We can easily point at Spanish (colonial) as well as native (Indian) features in both formal and semantic aspects of representations. However, Cuzco painting is not a matter of the past; nowadays there are still studies which produce neo-Baroque pictures, stylistically imitating old paintings. I would like to present neo-Baroque canvas and subsequent stages of work on them, using field research from 2013 and photographs taken in Galería de Artesanía "Fenix" in Cuzco, run by Luis Alfredo Pacheco Venero. What is important in the summary is reflections on cusqueñismo, a phenomenon typical of the city since the 1920 s and wondering whether within its scope there is a place not only for the Inca tradition but also for colonial art. Modern search for regional identity is not limited to the pre-Columbian era, but more and more often highly assesses the colonial legacy.

Key words: Cuzco painting; Baroque painting; colonial art; neo-Baroque; Peruvian art.

\section{Translated by Konrad Szulga}

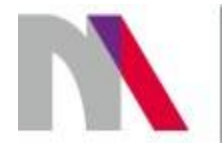

The preparation of the English version of Roczniki Humanistyczne (Annals of Arts) and its publication in electronic databases was financed under contract no. 836/P-DUN/2018 from the resources of the Minister of Science and Higher Education for the popularization of science.

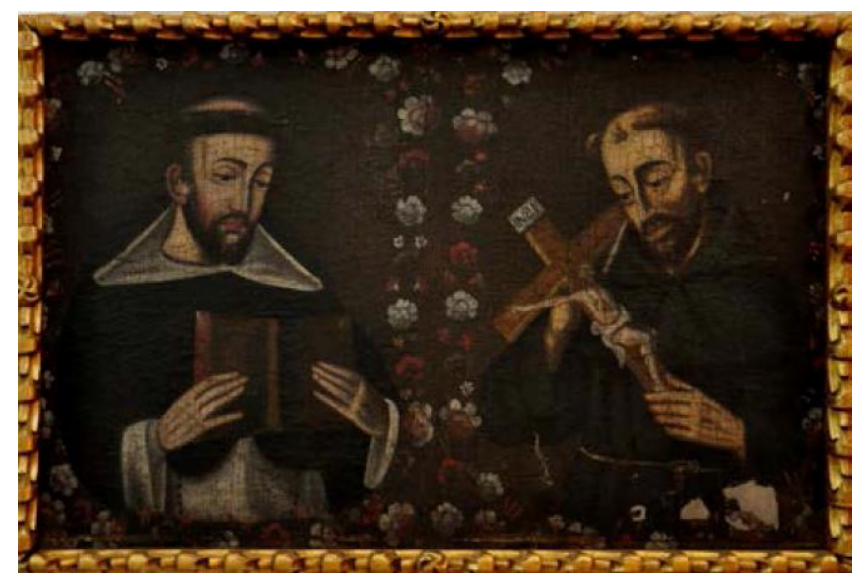

1. Images of St Dominic and St Francis, pinacotheca at Santa Catalina Monastery in Arequipa (Peru); photo by E. Kubiak, 2015 


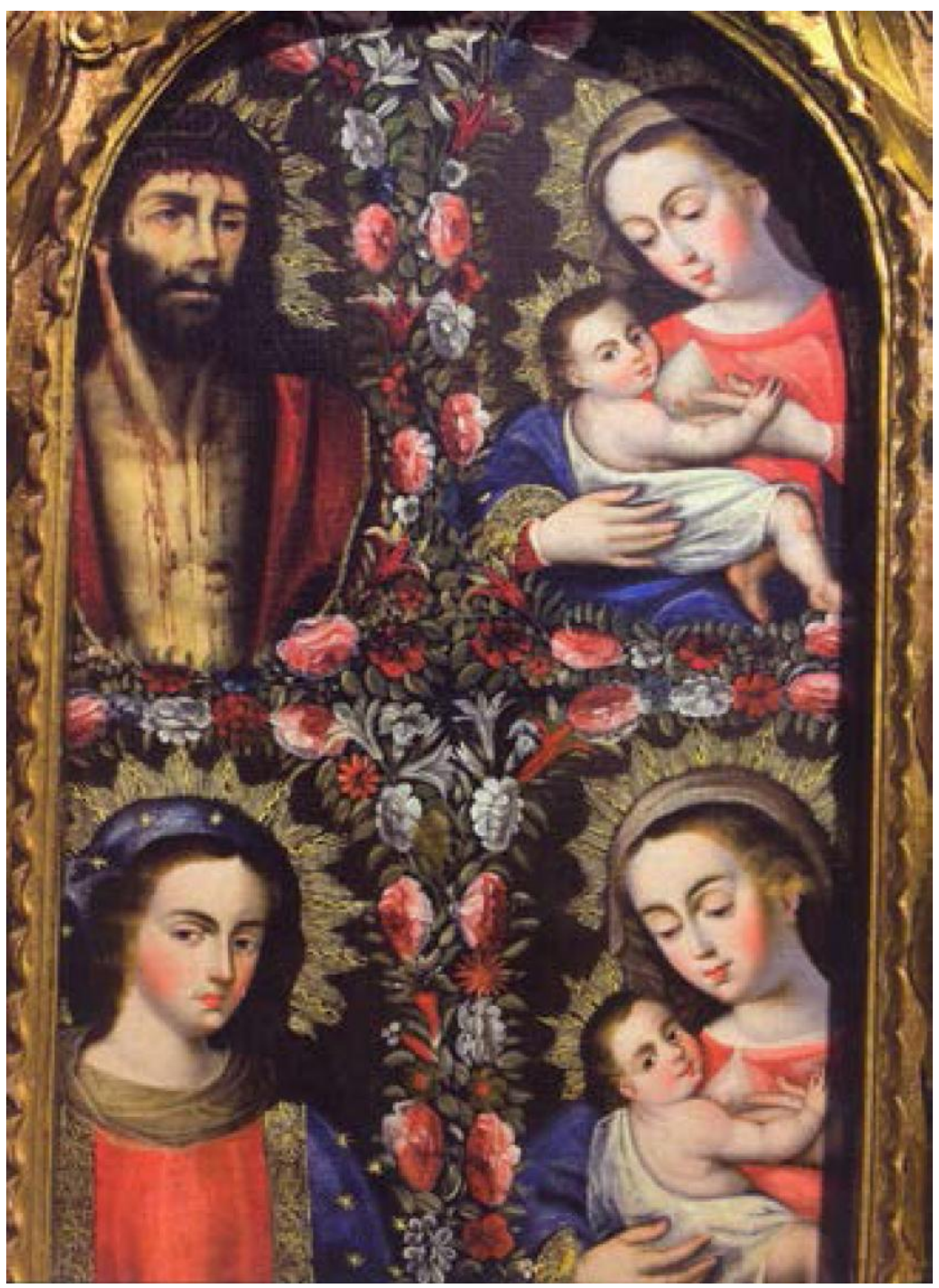

2. Canvas with four images (Christ the Sorrowful, Our Lady of Sorrows, two images of Madonna Lactans) from the church of San Francisco de Paula y Santa Cruz in Uquía (Argentina); Marta Penhos, "Pintura de la region Andina...," 871 


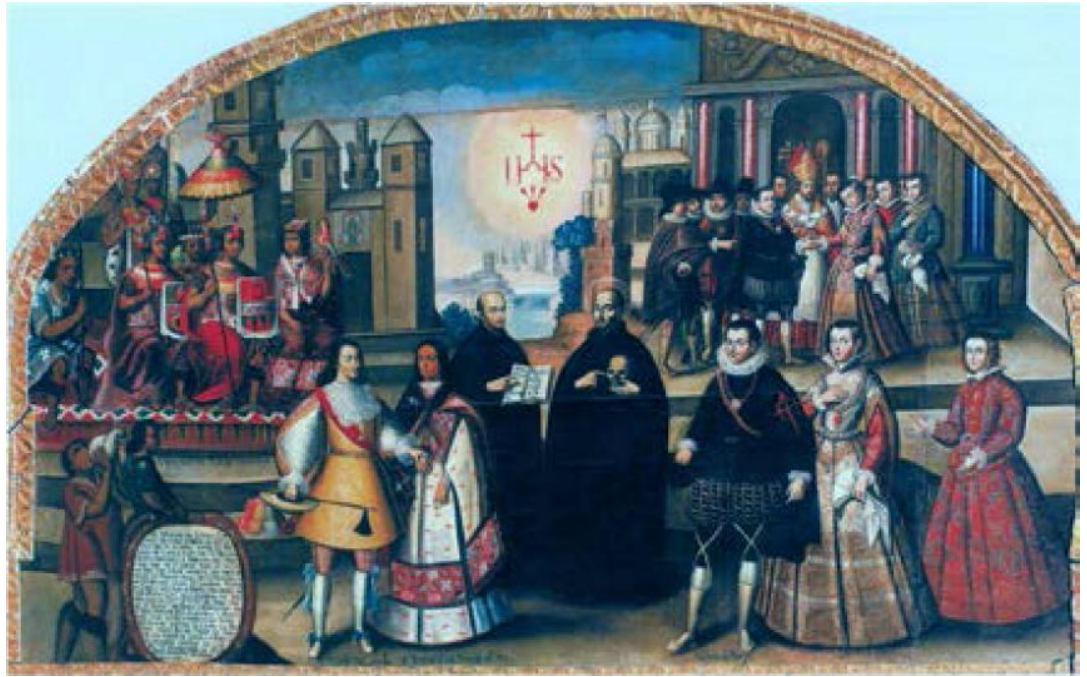

3. Marriage of captain-conquistador Martín de Loyola and ñusta Beatriz, daughter of an Inca named Sayri Tupak and of Juan de Borja and Lorenza ñusta de Loyola, $18^{\text {th }}$ century, Jesuit Church, Cuzco; Luis E. Wuffarden, "Iglesia y Colegio de la Transfiguración, Cuzco, Perú," 126
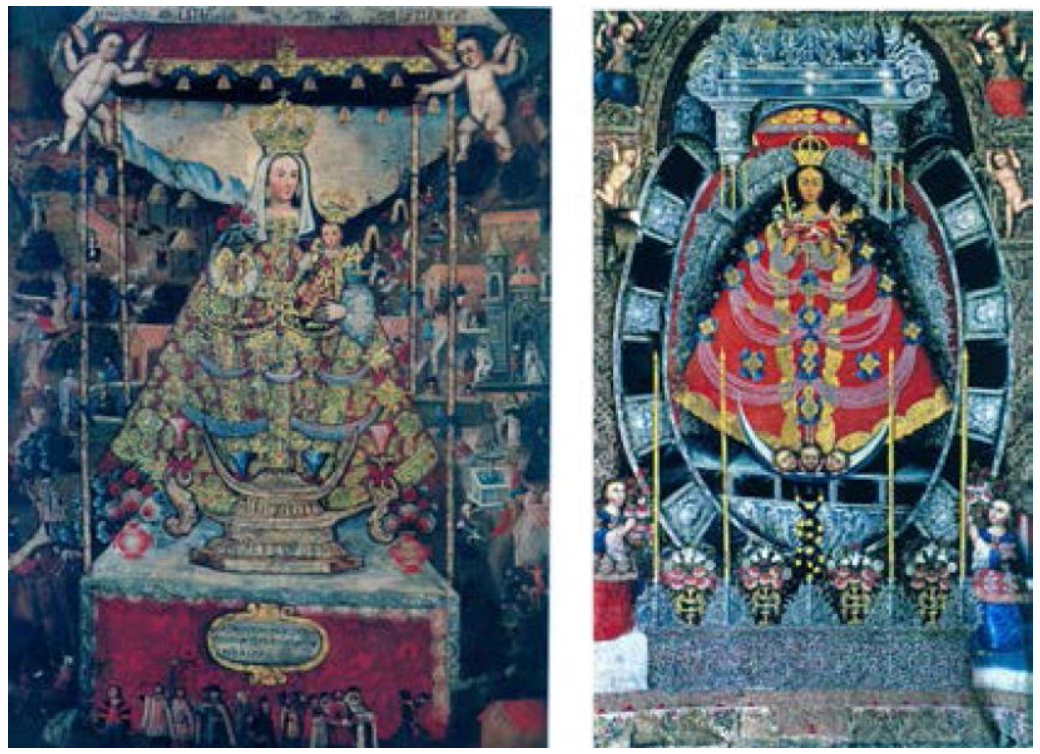

4. Marriage of captain-conquistador Martín de Loyola and ñusta Beatriz, daughter of an Inca named Sayri Tupak and of Juan de Borja and Lorenza nusta de Loyola, $18^{\text {th }}$ century, Jesuit Church, Cuzco; Luis E. Wuffarden, "Iglesia y Colegio de la Transfiguración, Cuzco, Perú," 126 

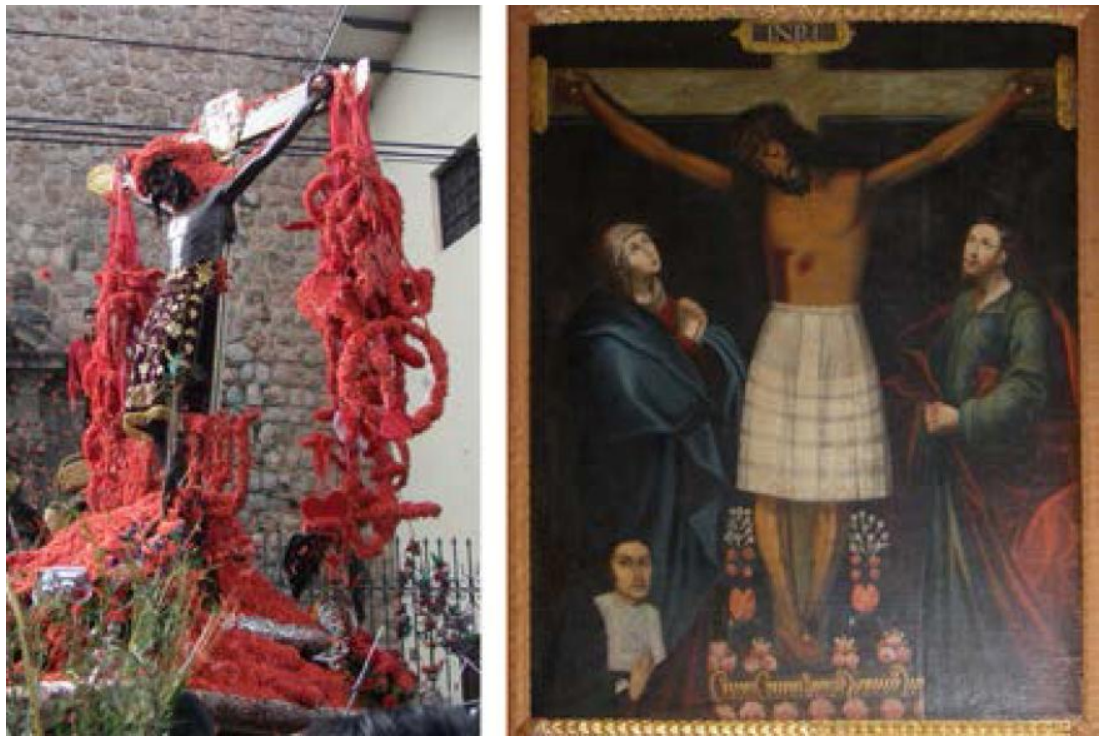

5. Cristo de los Temblores from the Cuzco cathedral, anonymous sculpture, $17^{\text {th }}$ century, Good Monday procession, Cuzco (photo by E. Kubiak, 2010); Cristo de los Temblores, anonymous painting, Las Nazarenas Monastery in Cuzco; photo by E. Kubiak, 2015

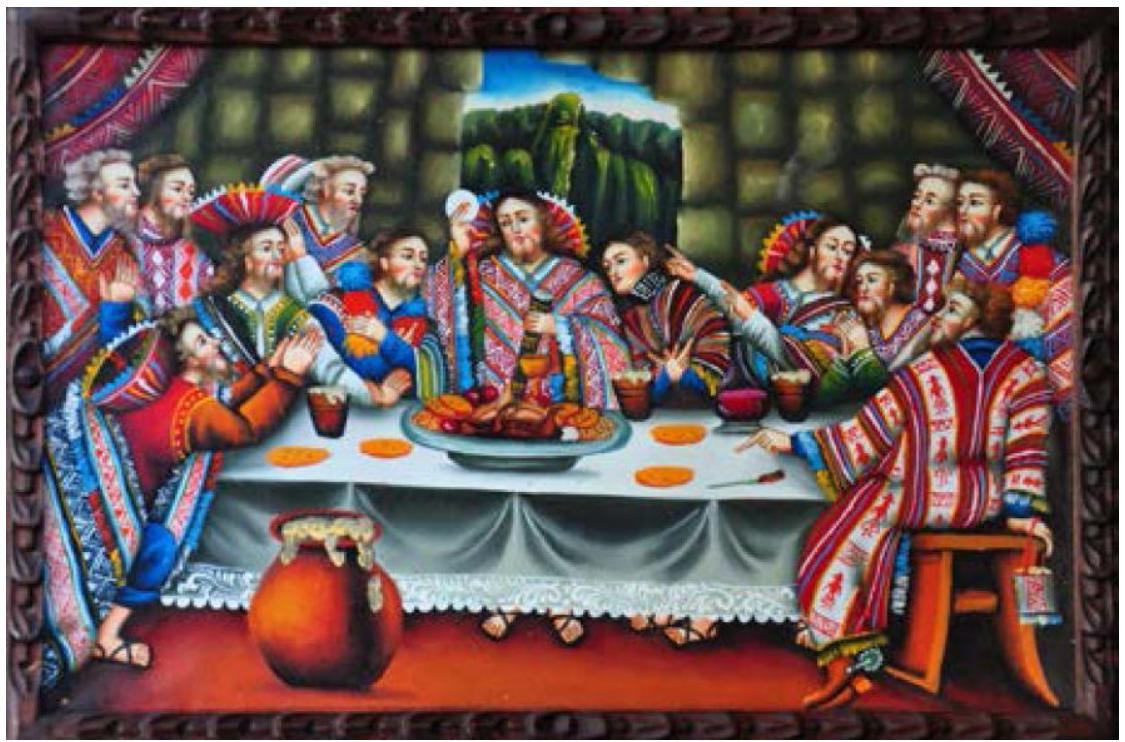

6. Last Supper, anonymous painting, private collection; photo by E. Kubiak, 2015 

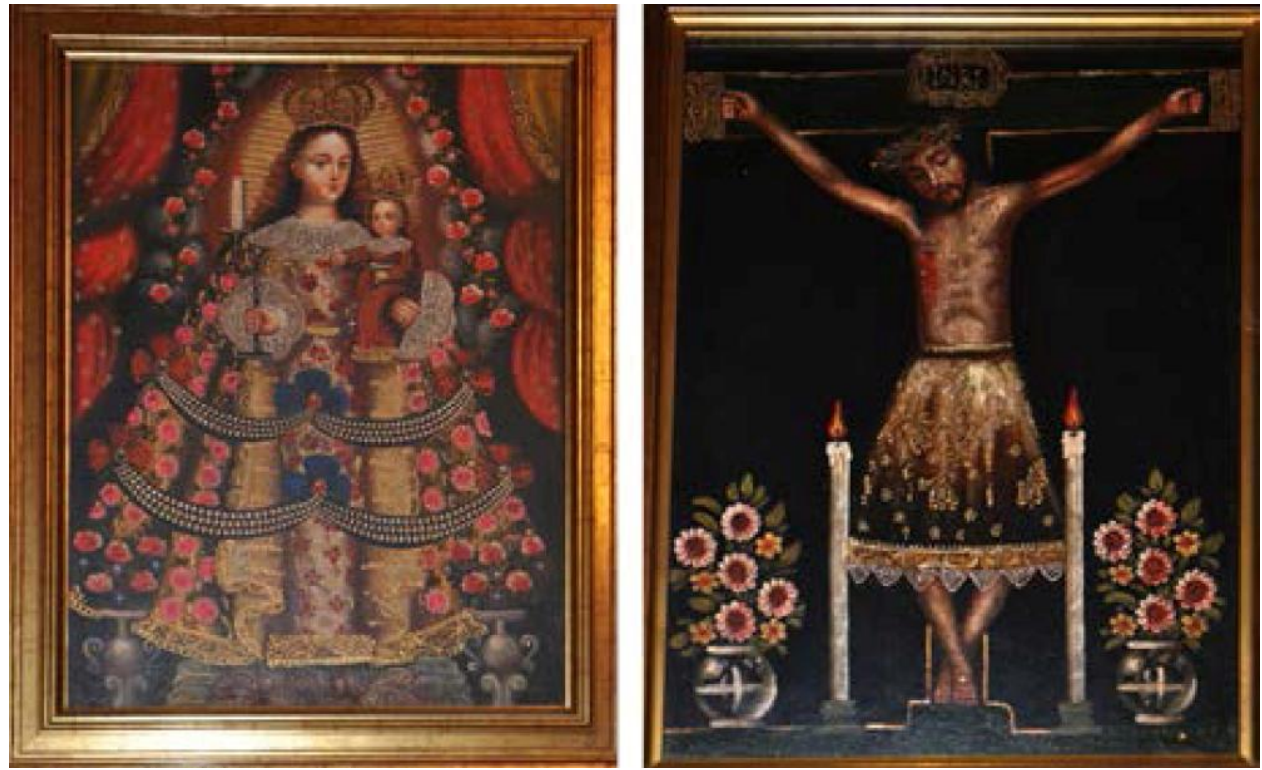

7. Virgen de Candelaria, anonymous painting, author's private collection; Cristo de los Temblores, anonymous painting, author's private collection; photo by E. Kubiak, 2016

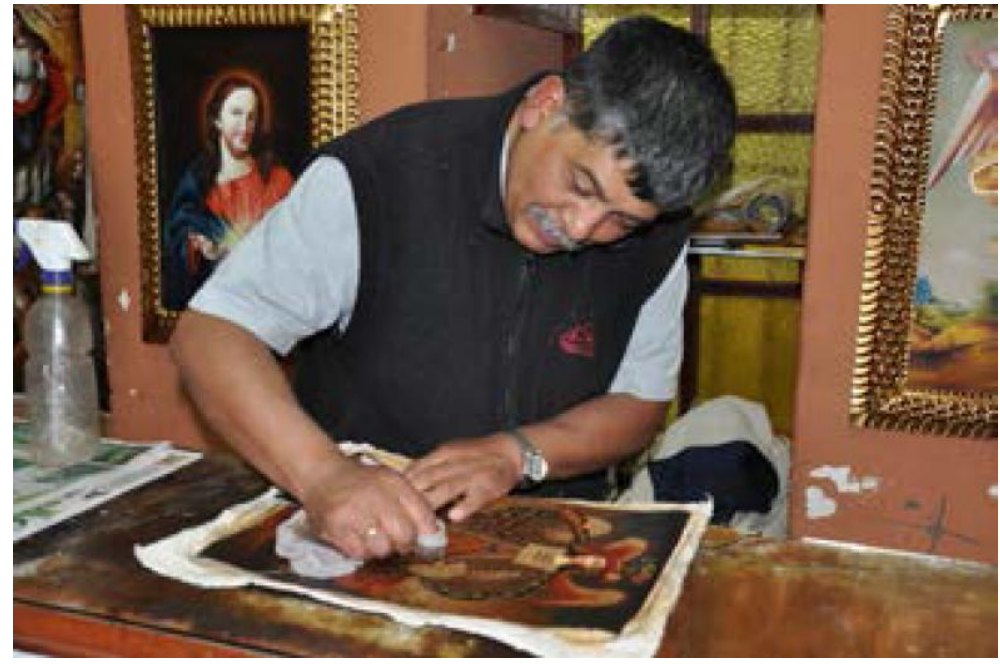

8. Luis Alfredo Pacheco Venero in his gallery working on finishing a new-Baroque painting portraying Angel the Arquebuser, Cuzco; photo by E. Kubiak, 2010 

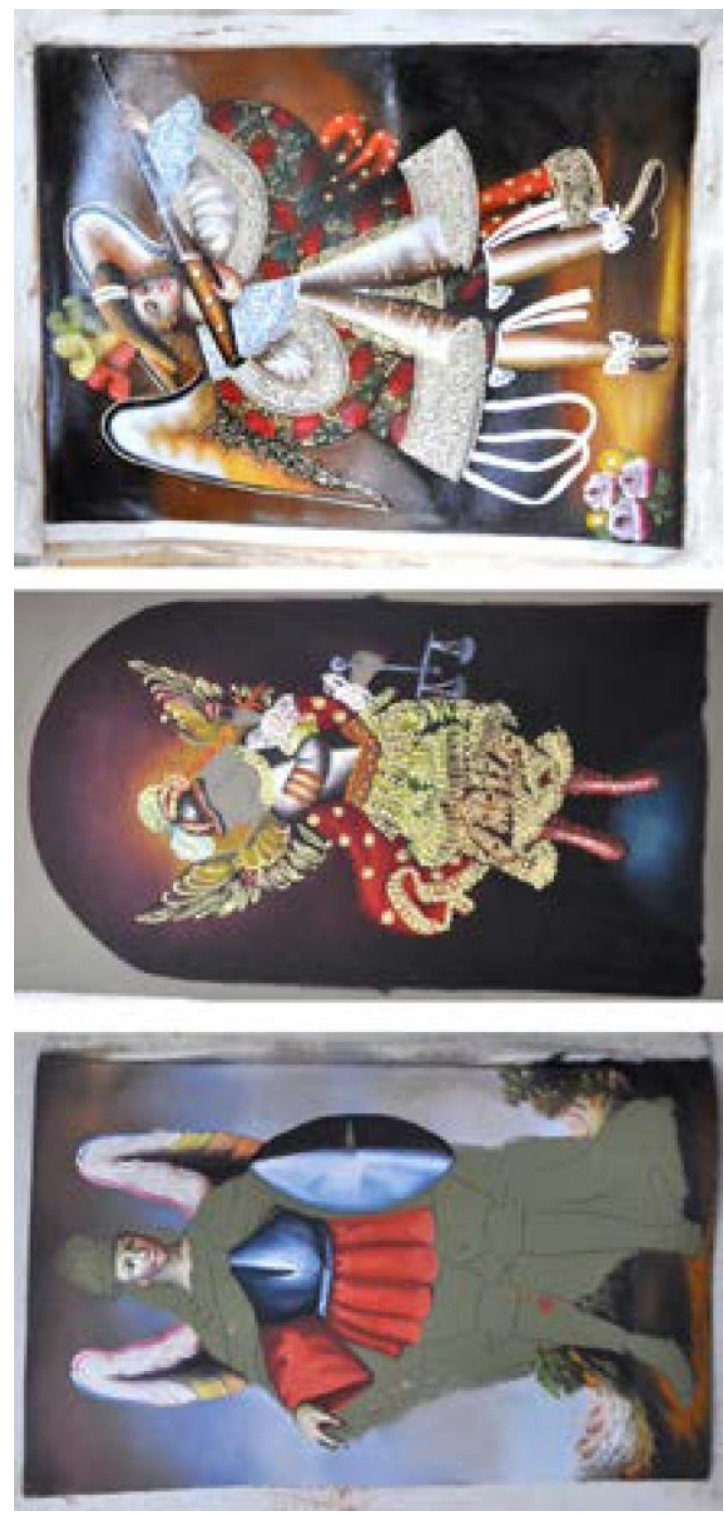

9. Successive stages of production of contemporary neo-Baroque canvas in Cuzco, photos taken at the Galería de Artesanía "Fenix" in Cuzco (owner: Luis Alfredo Pacheco Venero); photo by E. Kubiak, 2013 

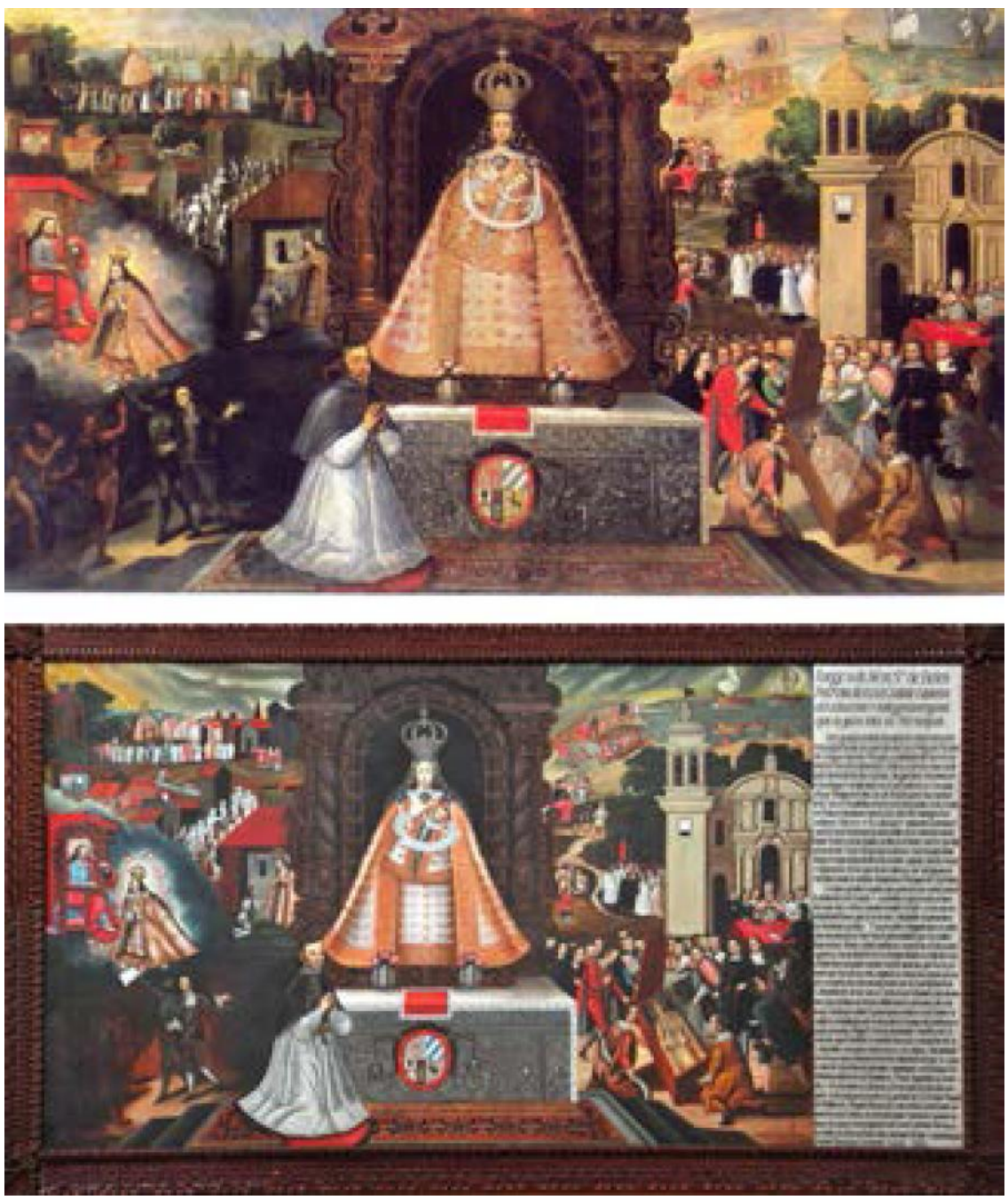

10. Basilio de Santa Cruz Pumacalla, Virgen de Belén con el obispo Manuel de Mallinedo y Angulo como donante (1693-1698), Catedral de Cusco, Perú; Copia de la obra de Basilio de Santa Cruz Pumacalla, Virgen de Belén con el obispo Manuel de Mallinedo y Angulo como donante, 2005, Iglesia de Nuestra Señora de Belén, Cusco, Perú; photo by E. Kubiak, 2012 

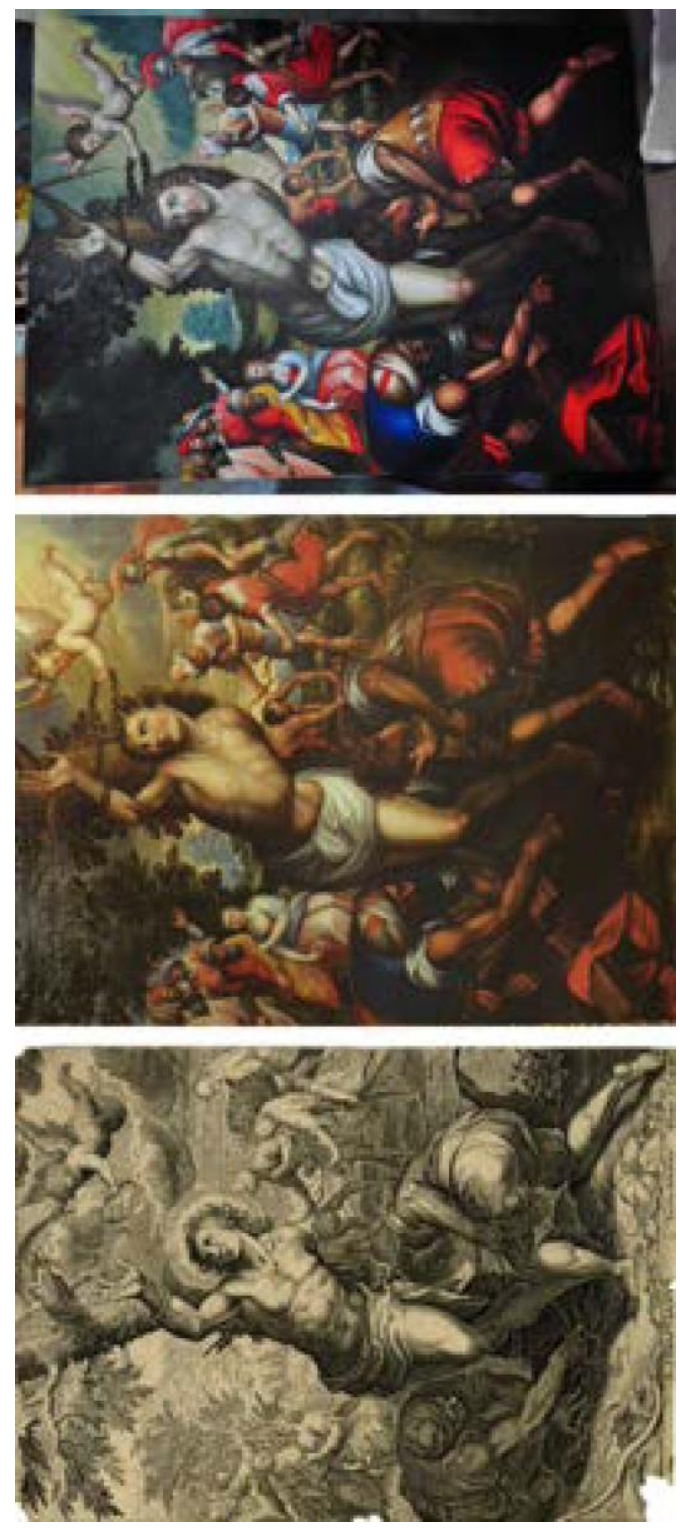

11. Thomas de Leu, St Sebastian, graphics modelled after the composition by Aegidius Sadaler II, based on a painting by Jacopo Palma the Younger; imitator of Diego Quipse Tito, St Sebastian, $17^{\text {th }}$ century, Museo de Santa Catalina, Cusco, Peru (source: www.colonialart.org); Robert Nilton Quispe Huari, St Sebastian, artist's own collection, study; photo by E. Kubiak, 2015 


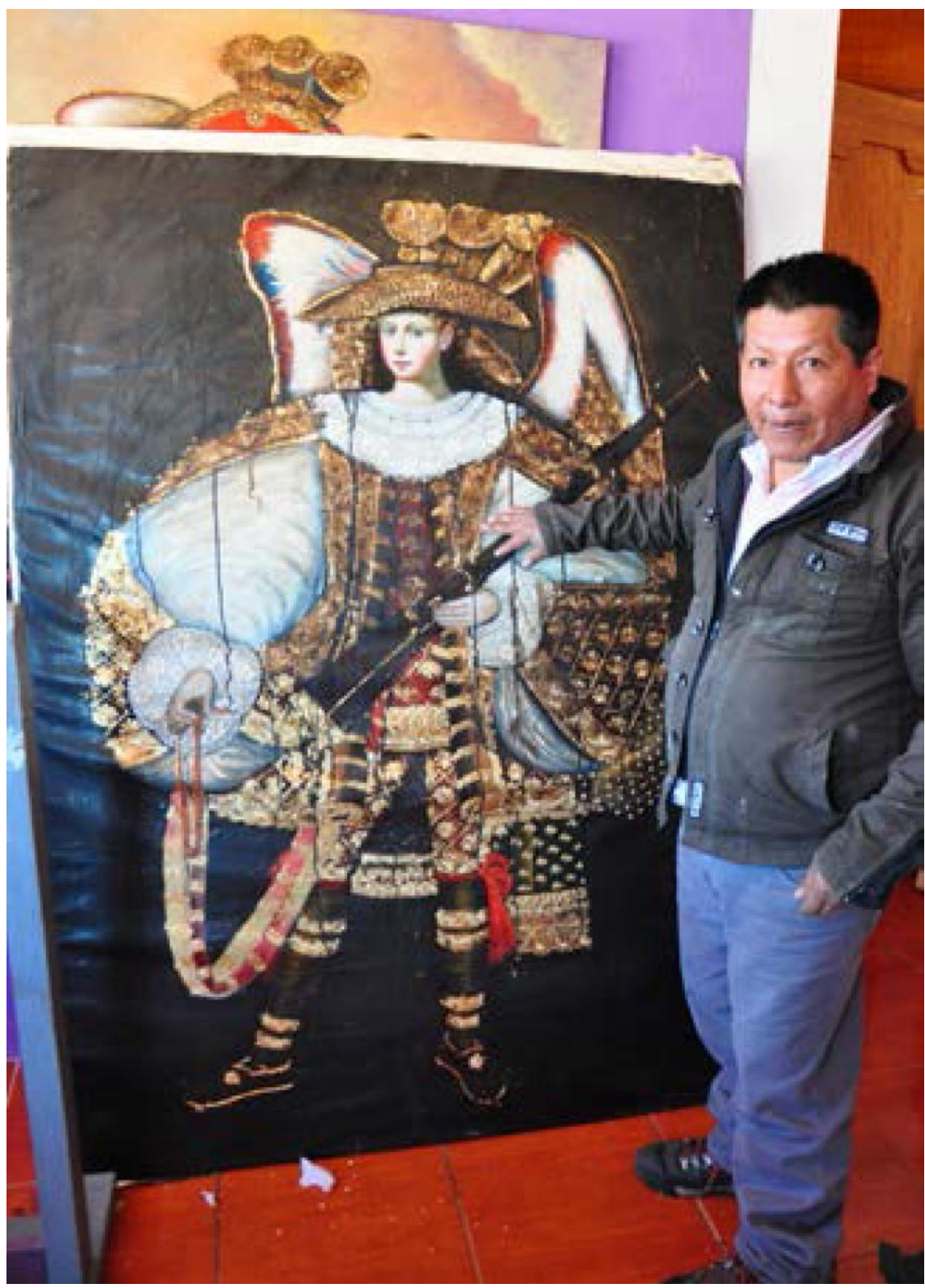

12. Artemio Coanqui Carrasco, the painter showing off the image with Angel the Arquebuser, artist's own collection, study; photo by E. Kubiak, 2015 

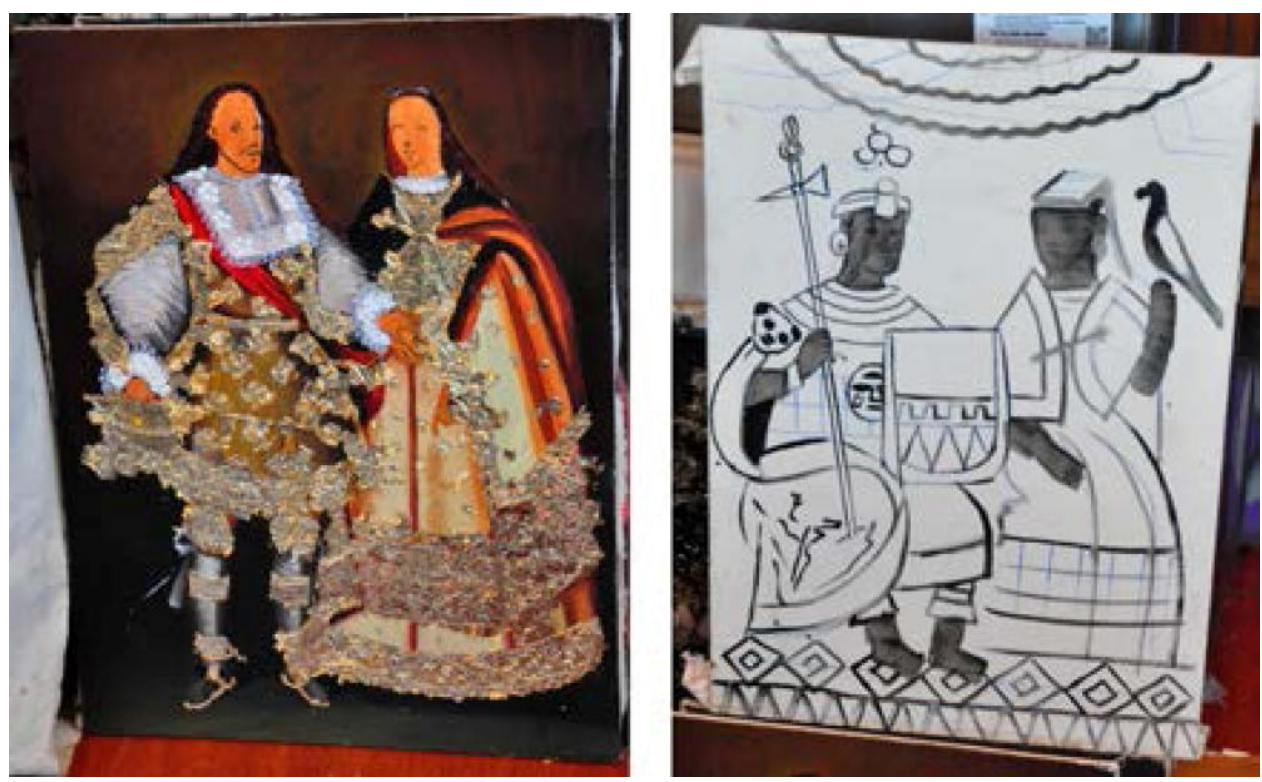

13. Artemio Coanqui Carrasco, Marriage ceremony of a conquistador and nusta, unfinished; Inca couple, sketch, artist's own collection, study; photo by E. Kubiak, 2015
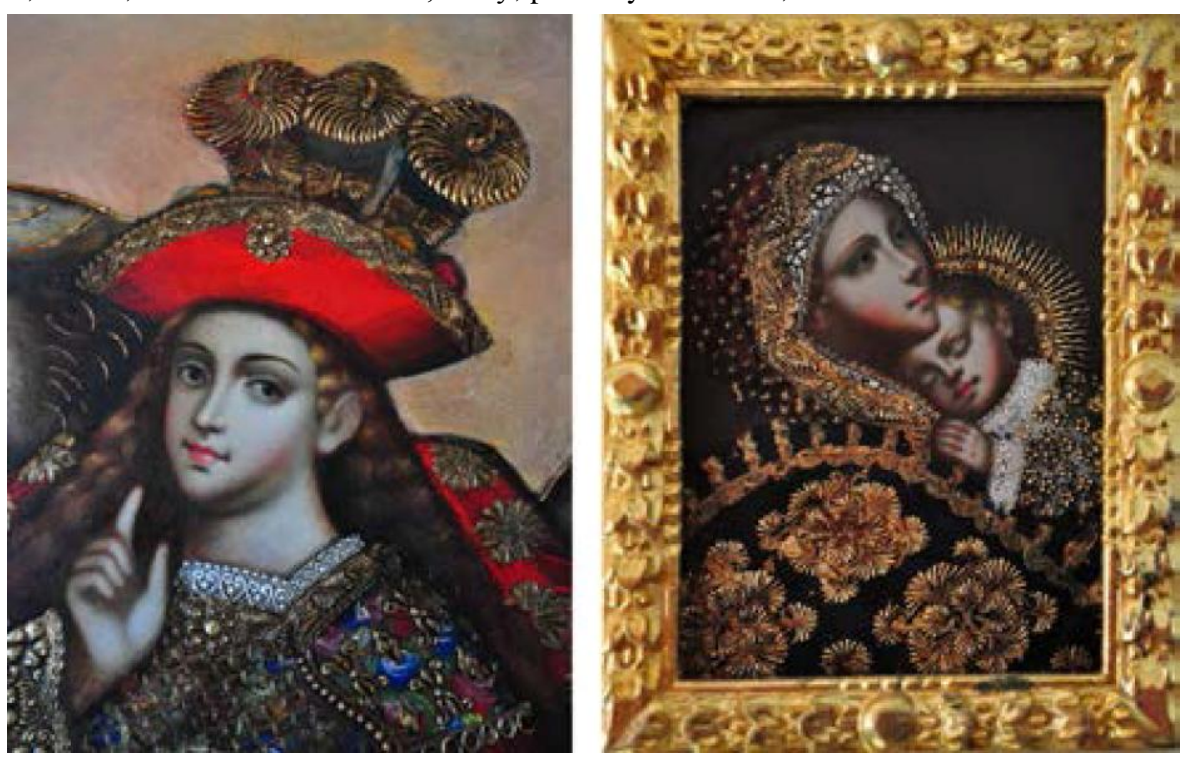

14. Artemio Coanqui Carrasco, Archangel Gabriel (fragment); Madonna with Child, artist's own collection, study; photo by E. Kubiak, 2015 